\title{
Development of a new index for methane drainageability of a coal seam using the fuzzy rock engineering system
}

The Mining-Geology-Petroleum Engineering Bulletin UDC: 622:08

DOI: $10.17794 / \operatorname{rgn} .2019 \cdot 4 \cdot 4$

Original scientific paper

\author{
Mehdi Najafi'; Ramin Rafiee ${ }^{2}$ \\ ${ }^{1}$ Department of Mining and Metallurgical Eng., Yazd University, Safayieh, P.O. Box: 89195-741, Yazd, Iran. \\ Email: mehdinajafi@yazd.ac.ir,https://orcid.org/0000-0002-1609-3702 \\ ${ }^{2}$ Faculty of Mining Eng., Petroleum and Geophysics, Shahrood University of Technology, Iran, RaminRafiee@Shahroodut.ac.ir
}

\begin{abstract}
Coal seam gas is one of the most significant energy resources in unconventional gas fields. The identification of influencing parameters and methane drainage assessment are, thus, a prime geotechnical focus for all potential methane drainage projects. In methane drainage operations of coal seams, many factors, such as natural factors and operational factors affect the drainage efficiency. In this paper, a new coal seam methane drainageability index (CMDI) is introduced for pre-drainage techniques in a working mine. In this approach, seventeen parameters are considered as the main factors affecting the methane drainage form coal seam, and the interaction matrix based on the fuzzy rock engineering system (FRES), which analyzes the interrelationship between the parameters affecting methane drainage activities, are used to study coal seam methane drainageability. Since the value of interaction in the RES method is not unique, the fuzzy system is used to minimize subjectivity of the weights which are computed in the RES method. The Tabas coal mine (Iran) was selected as a case study and the proposed index was used to rank the $C_{1}$ seam in this mine. It was observed that the methane drainageability index could suitably predict the potential of the methane drainage of coal seam. The newly proposed index can be used as a basis for decision-making when uncertainties about the evaluation of the parameters affect the methane drainage of a coal seam and reduce the risk of methane drainage projects.
\end{abstract}

\section{Keywords}

methane drainage, rock engineering system, fuzzy system, coal seam, unconventional gas, Tabas coal mine

\section{Introduction}

Coal seams may contain $60 \%$ to more than $95 \%$ methane that depend on the presence of other gases in the coal seam (Karacan et al., 2011; Darling, 2011; Wilson et al., 1995; Hamawand et al., 2013). Coalbed methane (CBM) also known as coal seam gas (CSG) is a natural gas that is stored (adsorbed) in coal seams. In the coal mine methane (CMM) method, gas is captured in working coal mines by underground or surface and underground methane drainage techniques to ensure the safety of a mine. In the enhanced coalbed methane (ECBM) method, the $\mathrm{CO}_{2}$ is injected into the coal bed and the methane gas is released by some chemical reactions and then it is extracted by a drainage operation (Thakur, 2014; Gale \& Freund., 2001; Wong et al., 2007; Karacan et al., 2011). CBM production behavior is complex and difficult to predict or analyze especially in the early stages of recovery. This is because gas production from CBM reservoirs is governed by a complex interaction of single phase gas diffusion through a matrix system and two-phase gas and water flow through a

Corresponding author: Mehdi Najafi

mehdinajafi@yazd.ac.ir cleat system that are coupled through a desorption process (Aminian et al., 2004). Coal mine methane can create a serious threat to mining safety and productivity due to its explosion risk. Methane drainage from a coal seam is used to improve the safety of coal mine extraction, reduce greenhouse gas emissions and improve mine economics by allowing a mine to produce coal with minimum methane levels (Warmuzinski, 2008; Karacan et al., 2011; Flores, 1998; Sereshki, 2005; Comfort et al., 1999).

Methane drainage methods involve the removal of methane prior to mining activity on a virgin coal seam and during extraction. The objective methane drainage caused increases the amount of gas removal from the underground mining districts and hence minimizes the gas flow into the mine airways (Diamond, 1994; Thakur, 2014). Based on the degree of gasification of a coal seam and discontinuities in overburdens, vertical boreholes, horizontal boreholes, gob gas ventholes and inclined boreholes can be used for methane drainage. The specifications of boreholes such as the number of boreholes, orientation, spacing, location and gasification time depend on the coal seam properties and other special conditions (Black, 2011; Diamond, 1994). Coal 
Table 1: The interactions of parameters in methane drainage from a coal seam

\begin{tabular}{|c|c|c|}
\hline Parameters & Effect on other parameters & References \\
\hline increasing the ash content & $\begin{array}{l}\text { - the adsorption capacity of coal decreases } \\
\text { - the gas production decreases }\end{array}$ & (Laxminarayana and Crosdale., 1999) \\
\hline increasing coal rank & $\begin{array}{l}\text { - gas content increases } \\
\text { - moisture content decreases } \\
\text { - decreased permeability } \\
\text { - an increase in cleat frequency }\end{array}$ & $\begin{array}{l}\text { (Moore, 2012; Sivek et al., 2010; Balan } \\
\text { and Gumrah., 2009; Ting, 1977) }\end{array}$ \\
\hline $\begin{array}{l}\text { increasing the degree } \\
\text { of saturation }\end{array}$ & $\begin{array}{l}\text { - gas production decreases from highly under } \\
\text { saturated zones with low permeability }\end{array}$ & (Black, 2011) \\
\hline increasing the depth & $\begin{array}{l}\text { - gas content increases } \\
\text { - decreases permeability } \\
\text { - moisture content decreases in most cases } \\
\text { - ash content increases }\end{array}$ & $\begin{array}{l}\text { (Paul and Chatterjee,2011; } \\
\text { (Siveketal.,2010) }\end{array}$ \\
\hline increasing the in-situ stress & $\begin{array}{l}\text { - permeability decrease } \\
\text { - Fracture systems close } \\
\text { - gas content increases }\end{array}$ & (Moore, 2012; Liu et al., 2016) \\
\hline increasing moisture content & - gas content decreases & (Levy et al., 1997) \\
\hline increasing cleat spacing & - permeability decreases & (Laubach et al., 1998) \\
\hline
\end{tabular}

seam methane drainage is influenced by various factors which are divided into two categories: geological and operational factors. The success of drainage operations is dependent on these factors. Numerous studies have attempted to investigate the effect of various factors on methane drainage from a coal seam. Karacan analyzed methane emission data from U.S longwall mining using multiple regression analysis and a neural network. The principal component analysis (PCA) was used to determine the weight of each parameter on methane emissions. PCA test models showed that gas content and seam thickness have the highest effect on gas emission from a coal seam (Karacan, 2009 a,b). Karacan analyzed the total gas flow rates and methane percentages from gob gas ventholes using a multilayer-perceptron (MLP) type artificial neural network (ANN). Also the sensitivity analysis was performed to determine the most important variables that affect venthole productions (Karacan, 2009). Karacan developed an expert classification system for U.S longwall degasification system selection. This model can be used as a decision tool for degasification system selection using site- and minespecific conditions (Karacan, 2009). Hemza et al. considered ten factors influenced on methane content of coal beds Czech Republic. Numerous analyses were performed to study the relationship between these factors and gas content (Hemza et al., 2009). Dougherty and Karacan discussed methane control and prediction (MCP) software which was developed by NIOSH. This software can determine the type of degasification system, predict the production performance of a gob gas venthole, predict ventilation emissions from longwall mines and predict the dynamic elastic properties of coal (Dougherty and Karacan, 2011). Black studied the relationship between gas production from underground inseam drainage boreholes, coal seam properties and op- erational factors. The results indicated that the degree of saturation and drainage time has a significant impact on gas production (Black, 2011). Dai et al. studied the effect of geological factors such as effective trapping thickness, moisture content and ash content on coal seam gas content. They used support vector machine (SVM) theory to set up a nonlinear prediction model for gas content prediction between coal seam gas content and main controlling factors (Dai et al, 2013). Zawadzki et al. estimated the methane content of a coal mine using multivariable geostatistic simulation. The desorption factor and coal strength index, both of which were used in cokriging and sequential Gaussian co-simulation (Zawadzki et al., 2013). Liu et al. studied the effect of various factors on $\mathrm{CBM}$ productivity using the analytic hierarchy process (AHP) method. The results indicated that the weight of geological factors, engineering factors and drainage factors are $50 \%, 25 \%$ and $25 \%$, respectively (Liu et al., 2014). In all those methods, the researchers did not consider all the parameters and their interactions completely.

There is an important point in methane drainage from a coal seam and its affecting parameters on each other. For example, increasing the value of one parameter causes an increase or decrease in the value of other parameters. Therefore, it is necessary to consider all parameter interactions completely. The interactions of some parameters in methane drainage are shown in Table 1.

Predicting the capability of a coal seam for methane drainage is an important issue in methane drainage systems. Therefore, the development of a new index that can classify the coal seam capability drainage by considering the interactions of influencing parameters is important. In such systems, the interactions of all influencing parameters (geological and operational) must be considered simultaneously. 


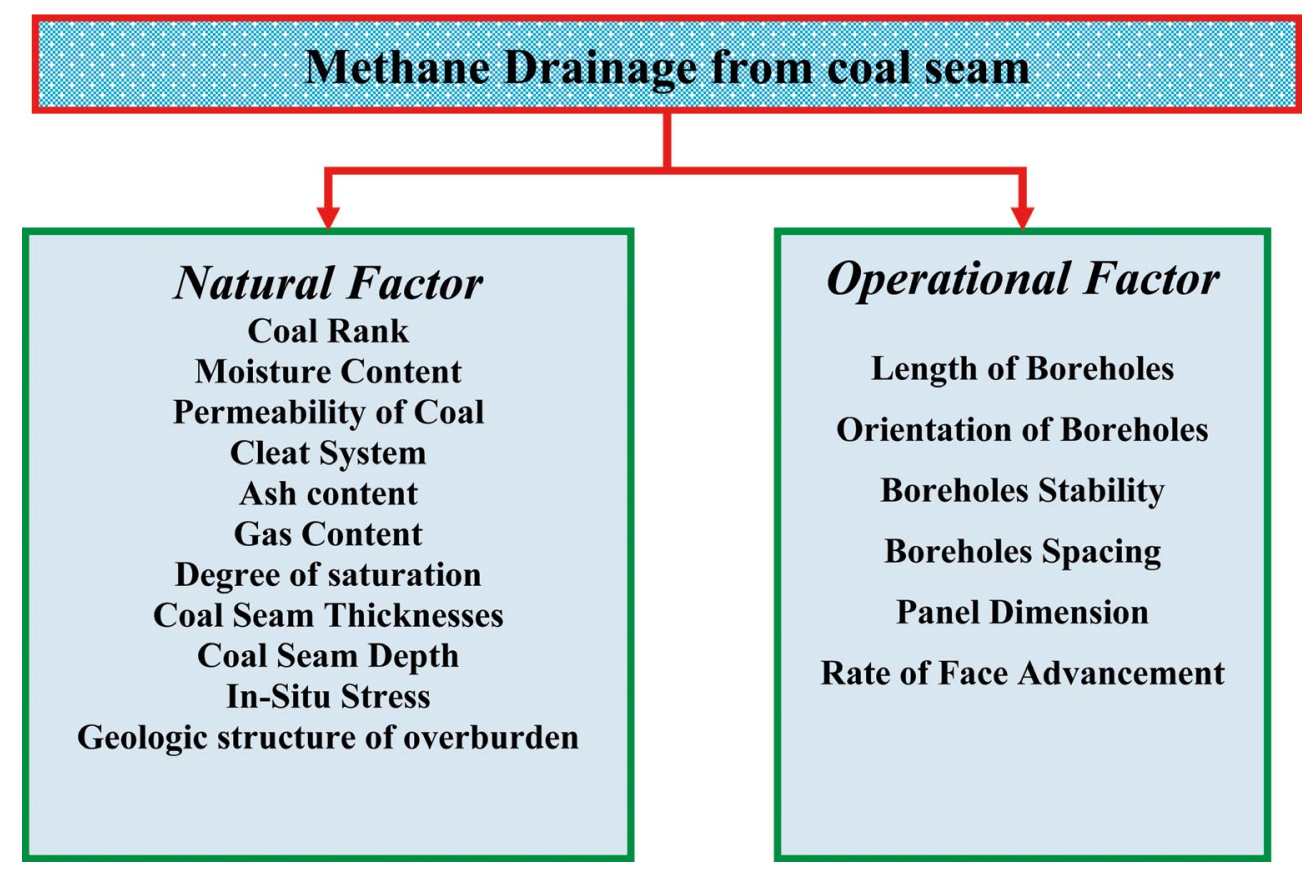

Figure 1: The main factors affecting methane drainage from a coalbed

(Black, 2011; Moore, 2012; Liu et al., 2016; Karacan, 2009 a,b)

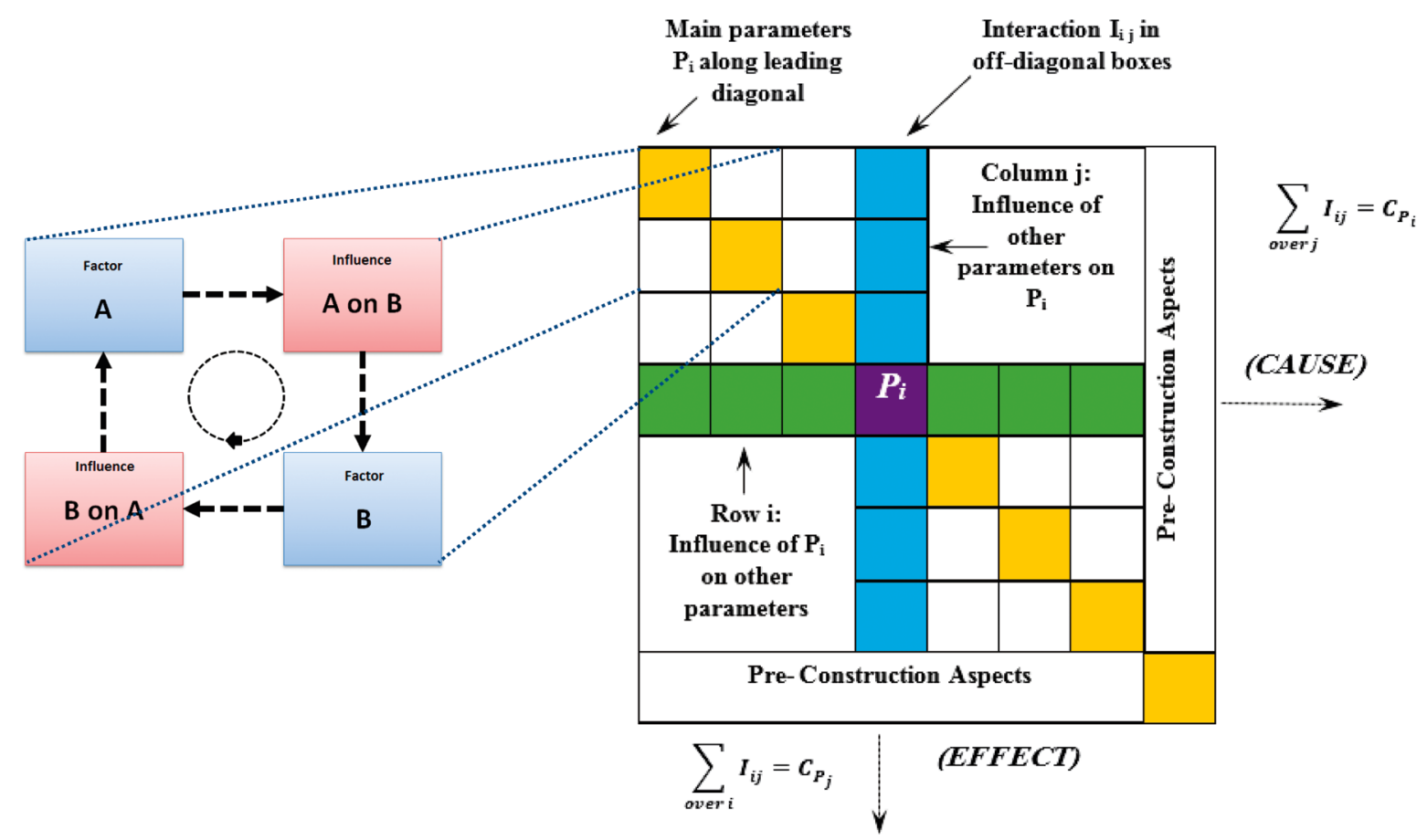

a: The principle of the interaction matrix with two factors

b: a general view details of the coding of interaction matrix

Figure 2: Summation of coding values in the row and column through each parameter to establish the cause and effect coordinates (Hudson, 1992)

The rock engineering system (RES) approach can be used for the analysis of coupled mechanisms in rock engineering problems (Hudson, 1992). In this approach, the main factors are listed along the main diagonal elements of a matrix, also called the interaction matrix, and the interrelations between pairs of factors are identified in off-diagonal elements. Many researchers have studied this method in various fields of rock mechanics and mining engineering such as Shang et al. (2000), Zhang et al. (2004), Rozos et al. (2008), Andrieux and Hadjigeorgiou (2008), Younessi and Rasouli (2010), Zare Naghadehi et al. (2013), Saeidi et al. (2013), Huang et al. (2013), Rafiee et al. (2015 a, b) and Rafiee et al. (2016). 
Table 2: Proposed range of affecting parameters on the coal seam methane drainage classification

\begin{tabular}{|c|c|c|c|c|c|}
\hline \multirow{2}{*}{ Parameters } & \multicolumn{5}{|c|}{ Rating } \\
\hline & 1 & 2 & 3 & 4 & 5 \\
\hline Coal Rank & Lignite & Sub-bituminous & Bituminous & Semi-anthracite & Anthracite \\
\hline Moisture Content (\%) & $>3$ & $2-3$ & $1-2$ & $0.5-1$ & $<0.5$ \\
\hline $\begin{array}{l}\text { Permeability of Coal } \\
\text { (md) }\end{array}$ & $<0.1$ & $0.1-1$ & $1-9$ & $10-50$ & $>50$ \\
\hline $\begin{array}{l}\text { Cleat System } \\
\text { (spacing }(\mathrm{cm}))\end{array}$ & $>20$ & $8-20$ & $3-8$ & $1-3$ & $<1$ \\
\hline Ash content (\%) & $>60$ & $40-60$ & $20-40$ & $10-20$ & $<10$ \\
\hline Gas Content (m3/t) & $<5$ & $5-10$ & $10-15$ & $15-20$ & $>20$ \\
\hline $\begin{array}{l}\text { Degree of saturation } \\
(\%)\end{array}$ & $0-20$ & $20-40$ & $40-60$ & $60-80$ & $80-100$ \\
\hline $\begin{array}{l}\text { Coal Seam Thicknesses } \\
\text { (m) }\end{array}$ & $<1$ & $1-2.5$ & $2.5-3.5$ & $3.5-5$ & $>5$ \\
\hline Coal Seam Depth (m) & $\begin{array}{l}>1000 \\
<100\end{array}$ & $100-400$ & $800-1000$ & $600-800$ & $400-600$ \\
\hline In-Situ Stress (MPa) & $>30$ & $20-30$ & $10-20$ & $5-10$ & $<5$ \\
\hline $\begin{array}{l}\text { Geologic structure } \\
\text { of overburden }\end{array}$ & $\begin{array}{l}\text { Very low gas } \\
\text { content and very } \\
\text { high permeability } \\
\text { of surrounding } \\
\text { rocks, } \\
\text { Very low strength } \\
\text { of hangingwall } \\
\text { and footwall, } \\
\text { High permeable } \\
\text { faults with low } \\
\text { gas and low } \\
\text { distance to each } \\
\text { other }\end{array}$ & $\begin{array}{l}\text { Low gas content } \\
\text { and high } \\
\text { permeability of } \\
\text { surrounding rocks, } \\
\text { Low strength of } \\
\text { hangingwall and } \\
\text { footwall, moderate } \\
\text { permeable faults } \\
\text { with low gas and } \\
\text { unsuitable distance } \\
\text { to each other }\end{array}$ & $\begin{array}{l}\text { Moderate gas } \\
\text { content and } \\
\text { permeability of } \\
\text { surrounding } \\
\text { rocks, } \\
\text { Moderate strength } \\
\text { of hangingwall } \\
\text { and footwall, } \\
\text { impermeable } \\
\text { faults with low } \\
\text { gas }\end{array}$ & $\begin{array}{l}\text { High gas content } \\
\text { and low } \\
\text { permeability of } \\
\text { surrounding } \\
\text { rocks, } \\
\text { Moderate strength } \\
\text { of hangingwall } \\
\text { and footwall, } \\
\text { impermeable } \\
\text { faults with } \\
\text { moderate gas }\end{array}$ & $\begin{array}{l}\text { Very high gas } \\
\text { content and very } \\
\text { low permeability } \\
\text { of surrounding } \\
\text { rocks, } \\
\text { High strength of } \\
\text { hangingwall and } \\
\text { footwall, } \\
\text { impermeable } \\
\text { faults with high } \\
\text { gas and suitable } \\
\text { distance to each } \\
\text { other }\end{array}$ \\
\hline $\begin{array}{l}\text { Length of Boreholes } \\
\text { (m) }\end{array}$ & $<100$ & $100-200$ & $200-400$ & $400-600$ & $600-1100$ \\
\hline $\begin{array}{l}\text { Orientation } \\
\text { of Boreholes to the } \\
\text { principal horizontal } \\
\text { stress) (Degree) }\end{array}$ & $70-90$ & $40-70$ & $15-40$ & $3-15$ & $0-3$ \\
\hline $\begin{array}{l}\text { Boreholes and Wellbore } \\
\text { Stability }\end{array}$ & instable & Very low stability & Low stability & Moderate stability & High Stability \\
\hline Boreholes Spacing (m) & $>60$ & $30-60$ & $15-30$ & $5-15$ & $<5$ \\
\hline $\begin{array}{l}\text { Panel Dimension } \\
\text { (Width and Length) } \\
\text { (m) }\end{array}$ & $\begin{array}{l}\mathrm{W}<150 \\
\quad \text { or } \\
\mathrm{L}<600\end{array}$ & $\begin{array}{c}\mathrm{W}=150-200 \\
\text { or } \\
\mathrm{L}=600-1000\end{array}$ & $\begin{array}{c}\mathrm{W}=200-250 \\
\text { or } \\
\mathrm{L}=1000-1500\end{array}$ & $\begin{array}{c}\mathrm{W}=250-300 \\
\text { or } \\
\mathrm{L}=1500-2000\end{array}$ & $\begin{array}{c}\mathrm{W}>300 \\
\text { or } \\
\mathrm{L}=2000-3500\end{array}$ \\
\hline Cut Depth (cm) & $<70$ & $70-80$ & $80-90$ & $90-100$ & $>100$ \\
\hline
\end{tabular}

The aim of this research is to propose a new index for assessing the drainageability of a coal seam using the fuzzy rock engineering system. Therefore, by using the FRES method first, the parameters with the highest effect on the methane drainage are found and then a new index is presented to predict the coal seam methane drainage potential for pre-drainage techniques.

\section{Factors influencing methane drainage}

In the first step, the parameters that influence the methane drainage have been identified. According to lit- erature and various studies, the most important factors influencing methane drainage from a coal seam can be categorized into two types: natural factors and operational factors. These parameters are shown in Figure 1.

\section{Rock engineering system}

The concept of the rock engineering system (RES) approach was first introduced by Hudson for solving complex engineering problems. This approach can be used for the analysis of coupled mechanisms in rock engineering problems (Hudson, 1992). The RES uses a 


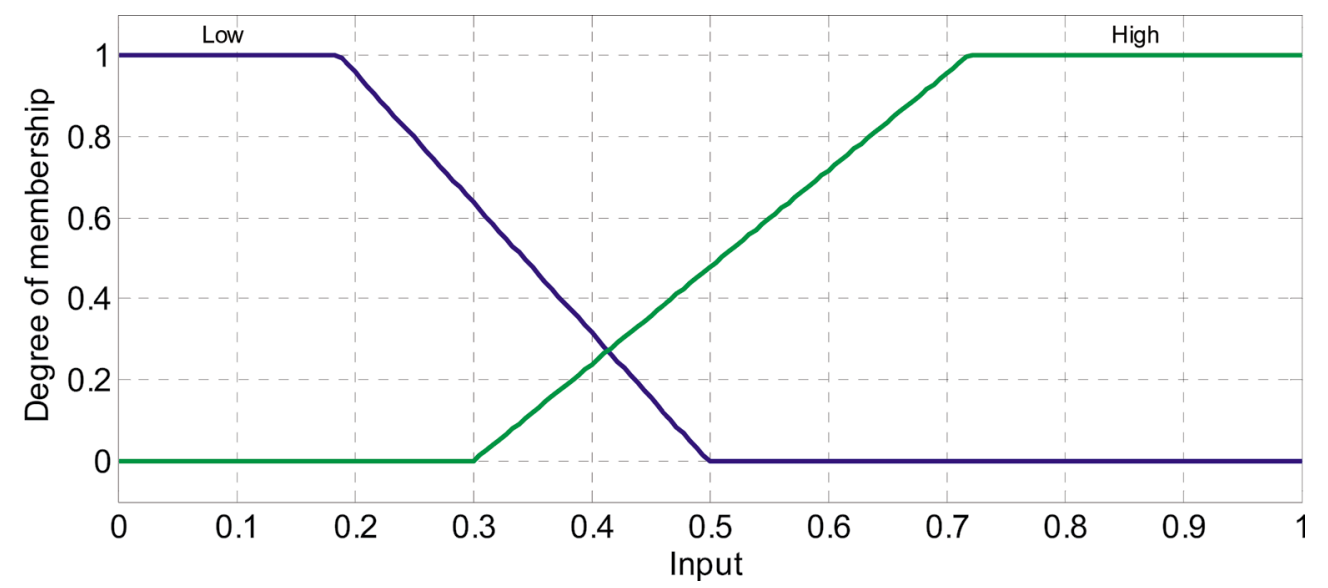

Figure 3: Fuzzy set for each fuzzy system input

top-down analytic model to treat the rock mass, the boundary conditions, and the engineering activities as a complete, interactive, and dynamic system. The key element in the RES method is the interaction matrix. The interaction matrix is a basic technique for characterizing the important parameters and the interaction mechanisms in a rock engineering system. In the interaction matrix, all parameters influencing the system are arranged along the leading diagonal of the matrix, called the diagonal terms. Otherwise, the influence of each individual parameter on any other parameters is included at the corresponding off-diagonal position of the matrix. The off-diagonal terms are assigned numerical values which describe the influence degree of one parameter on the other parameters. Assigning these values are usually referred to as "coding the matrix". Several coding methods have been developed for this purpose, with the most common being the 'expert semi-quantitative' (ESQ) coding method (Hudson, 1992). ESQ coding has been used in nearly all previous works. In this method, one unique code is assigned to each interaction, thereby expressing the influence of a parameter on another in the matrix. Typically, coding values vary between 0 and 4 with 0 indicating no interaction, 1 indicating a weak interaction, 2 indicating a medium interaction, 3 indicating a strong interaction and 4 indicating a critical interaction. An interaction matrix is illustrated in Figure 2. After coding the interaction matrix by inserting the appropriate values for each off-diagonal cell of the matrix, the influence of each parameter on the system is named "cause" (Ci) and the effect of the system on each parameter is named "effect" (Ei) (see Figure 2).

The C-E diagram is created by $\left(\mathrm{C}_{\mathrm{i}}, \mathrm{E}_{\mathrm{i}}\right)$ coordinate values plotted in cause and effect space. From this diagram "less interactive" and "more interactive" parameters are determined (Hudson, 1992).

\section{Coal seam methane drainageability index (CMDI)}

As mentioned in section 2, many parameters affect coal seam methane drainage. In this study, seventeen pa- rameters are considered as the main factors affecting the methane drainage from a coal seam and the importance and physical ranges of parameters, also the corresponding ratings, are listed in Table 1. It is notable that the values of the parameters are divided into five classes and each class ranges from 1 to 5 . The ranges of parameters in Table 2 were proposed based on the judgments of experienced experts in field methane drainage and also the results obtained from literature review.

\subsection{Definition of the coal seam methane drainageability index (CMDI) using the fuzzy rock engineering system}

As previously mentioned in the ESQ coding method, one value is deterministically assigned to each interaction. Therefore, in order to consider the uncertainties of the influence of one parameter on the others, the "Fuzzy ESQ" (FESQ) coding approach was used.

The first step is to form the interaction matrix between effective parameters on coal seam methane drainageability. Then, questionnaires were prepared and ten experts were asked to determine the value of the interaction between each pair of parameters.

In order to defuzzify the interaction matrix, for each element of the matrix, the number of each state of interaction based on the experts' decisions is considered. The states of interaction are named as $n_{A}$ (number of no interaction), $n_{B}$ (number of weak interactions) $n_{C}$ (number of medium interactions) $n_{E}$ (number of strong interactions) and $n_{F}$ (number of critical interactions). These values are firstly normalized and then used as the input of the fuzzy system. For each fuzzy system input, two fuzzy sets "Low" and "High" are considered which are shown in Figure 3. For example, if $n_{\mathrm{F}}$ is "Low" this means that most of the experts stated there is no critical interaction, and the probability of mode $F$ (critical interaction) is lower (Rafiee et al. 2015).

When the normalized value for each element in the interaction matrix is less than 0.4, the MF (membership function) value of "Low" set is greater and the MF value 


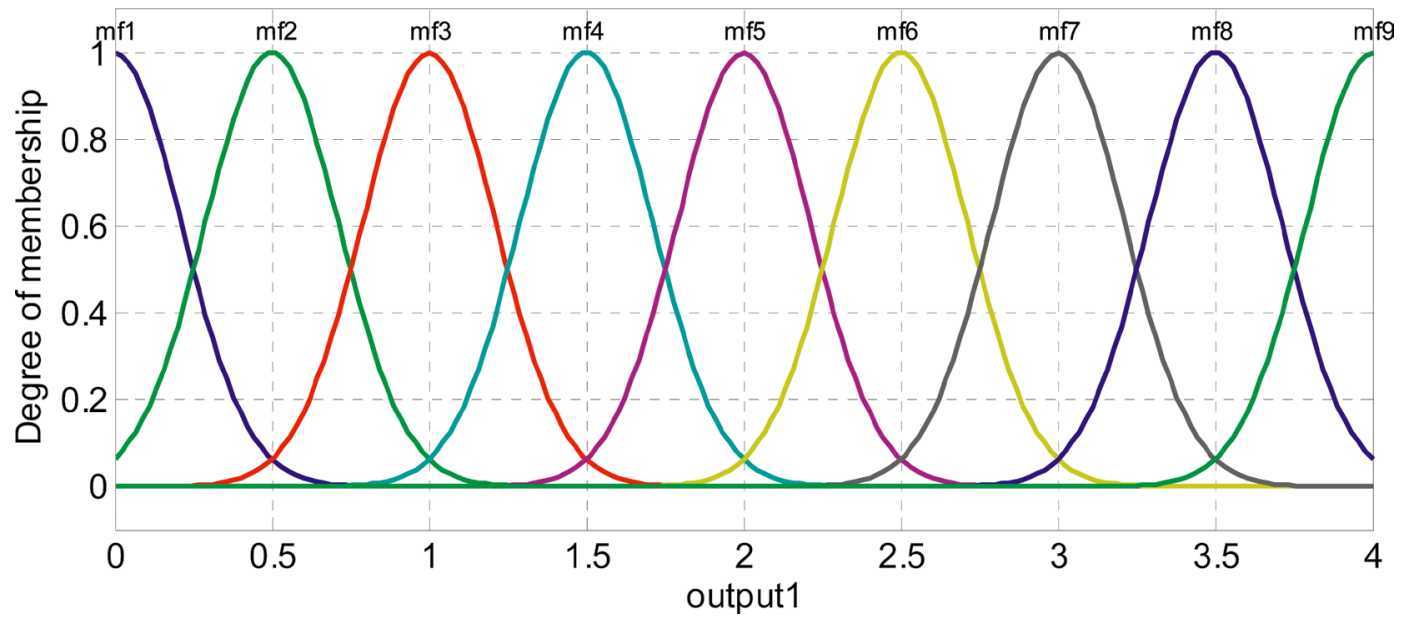

Figure 4: Output of fuzzy system

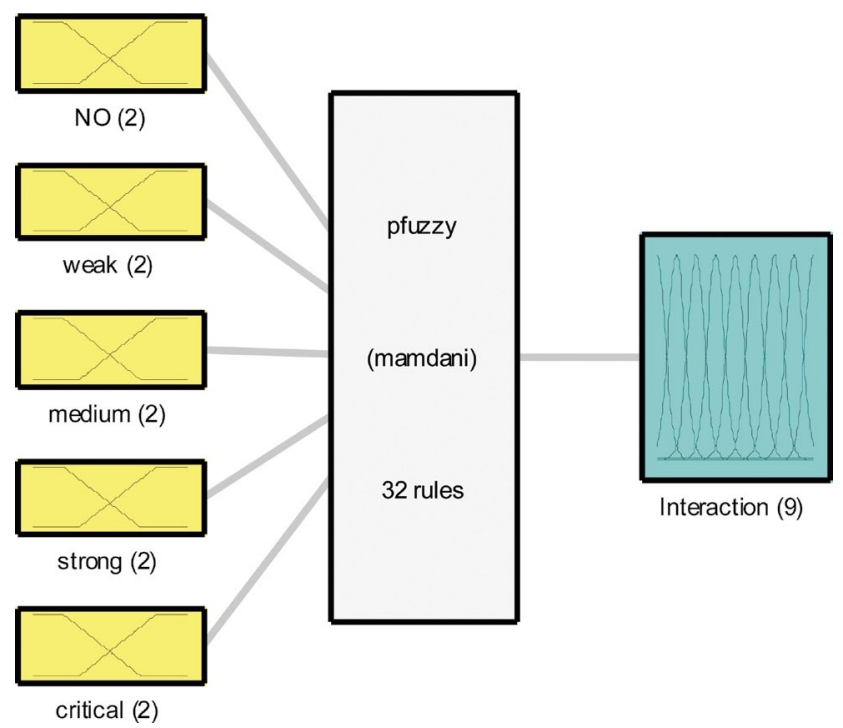

Figure 5: Fuzzy system with 5 inputs, 32 rules and 1 output

of "High" set is lower and vice versa. It is noteworthy, the choice of the "Low" and "High" membership function for each input of fuzzy system have been appointed based on the experts' judgment (Rafiee et al. 2015). To increase the precision of the intermediate state of the output, the $m_{1}$ to $m_{9}$ fuzzy sets are defined between 0 and 4 for output of the fuzzy system. The output of fuzzy system form is shown in Figure 4. According to five inputs and considering two modes for each input, $2^{5}$ rules could be defined. In Figure 5, a fuzzy system with 5 inputs, one output and 32 rules is shown.

Considering the fuzzy system, the RES interaction matrix can be coded. Afterward, by using the value of parameters and their corresponding 'weights', the methane drainageability index for a coal seam can be calculated.

Hudson proposed a method for determining a weight for each parameter. For this purpose, in the first step, the cause $\left(C_{i}\right)$ and effect $\left(E_{i}\right)$ values for each parameter in the system is calculated by Equation 1 and 2 (Hudson, 1992).

$$
\begin{aligned}
& C_{i}=\sum_{n} I_{m n}(\text { with } m \equiv i) \\
& E_{i}=\sum_{m} I_{m n}(\text { with } n \equiv i)
\end{aligned}
$$

Where:

$I_{m n}$ - interaction matrix element

$C_{i}-$ sum of the raw values

$E_{i}$ - sum of the column values for each parameter

Then, the weight of each parameter is determined using following Equation 3 (Hudson, 1992).

$$
w_{i}(\%)=\left(\frac{\frac{1}{M P_{i}} \times\left(C_{i}+E_{i}\right)}{\sum_{j}\left(C_{j}+E_{j}\right)}\right) \times 100
$$

Where:

$M P_{i}$ - The rating value assigned to the different category of the parameter $i$.

Therefore, the weight for parameter $i$, which is shown by $w_{i}$, is calculated by its 'parameter interaction intensity' $\left(C_{i}+E_{i}\right)$ divided by the sum of interaction intensities of all parameters in the system (Hudson, 1992). After the weights for all parameters $\left(w_{i}\right)$ were calculated, the coalbed methane drainageability index (CMDI) is calculated by Equation 4.

$$
C M D I=\sum_{i} w_{i} \times P_{i}
$$

Where:

$w_{i}$ - weights of parameters

$P_{i}$ - assigned values to each input parameter considered for coal seam methane drainageability.

In the following section, the proposed coal seam methane drainageability index (CMDI) is calculated for the Tabas coal mine and is used to assess the coal seam methane drainageability. 


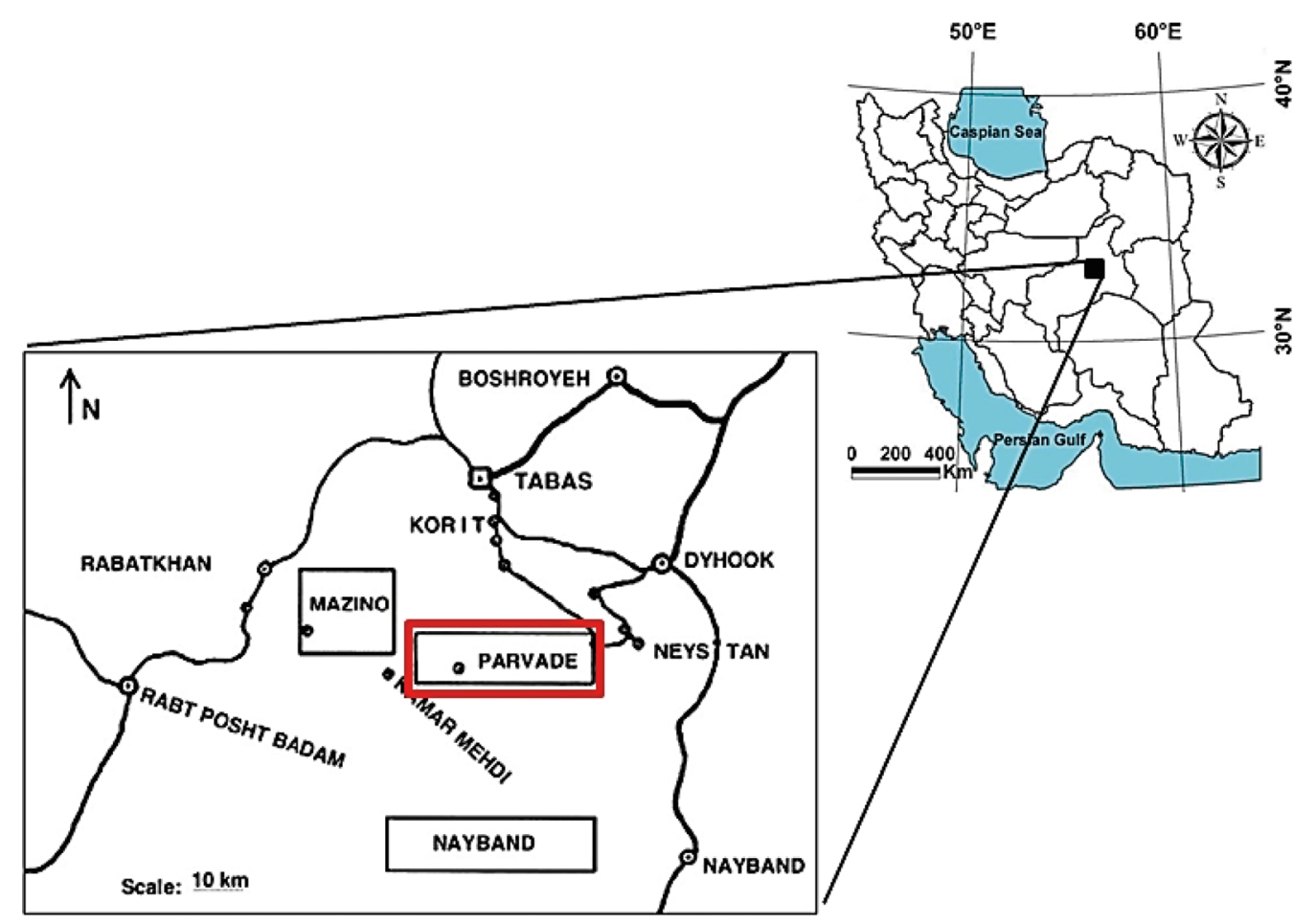

Figure 6: Location map showing the Tabas coal mine (Najafi et al., 2014)

\subsection{Case study: Tabas coal mine}

The Tabas coalfield is one of the most important coalfields in Central Iran. The area is located in the central desert of Iran, very far from any inhabited areas. The Tabas coalfield consists of the Mazino, Parvadeh and Nayband coal deposits. Coal-bearing strata in the Parvadeh deposit are within the Triassic formations. The rank of the Parvadeh deposit is anthracite and all of the coal seams are formed within the complicated monoclines and synclinal folds. The geology of the area is within a syncline which has been deepened to the east, and has been cut by several faults. Parvadeh coal deposit consists of five coal seams $\left(\mathrm{C}_{1}, \mathrm{C}_{2}, \mathrm{D}, \mathrm{B}_{1}\right.$ and $\left.\mathrm{B}_{2}\right)$. It has three minable seams $\left(\mathrm{C}_{1}, \mathrm{~B}_{1}\right.$ and $\left.\mathrm{B}_{2}\right)$. The coal seam gas content in the Parvadeh coal deposit increased to a depth of $300 \mathrm{~m}$ with a value of $19 \mathrm{~m}^{3}$ per ton and then it will be constant. In this deposit, the gas content of the surrounding rocks of the coal seam is $3-5 \mathrm{~m}^{3}$ per ton at a depth of $500 \mathrm{~m}$ (Anon, 2005).

The Tabas coal mine is located in the Tabas coal region approximately $85 \mathrm{~km}$ south of Tabas in the South Khorasan province, Iran (see Figure 6). The $C_{1}$ seam which is located in the Tabas coal mine is mined by a mechanized longwall retreat mining method. The thickness and dip of the $\mathrm{C}_{1}$ seam vary from 1.5 to 3 meters (approximately $2.2 \mathrm{~m}$ ) and from 5 to 26 degrees, respectively. Intermittently low strength sandstone and siltstone layers form in the hangingwall of the coal seam. The distance between the $\mathrm{C}_{1}$ seam and $\mathrm{C}_{2}$ is approximately $12.9 \mathrm{~m}$. The footwall consists of siltstone and mudstone seams (see Figure 7). The orientation of the

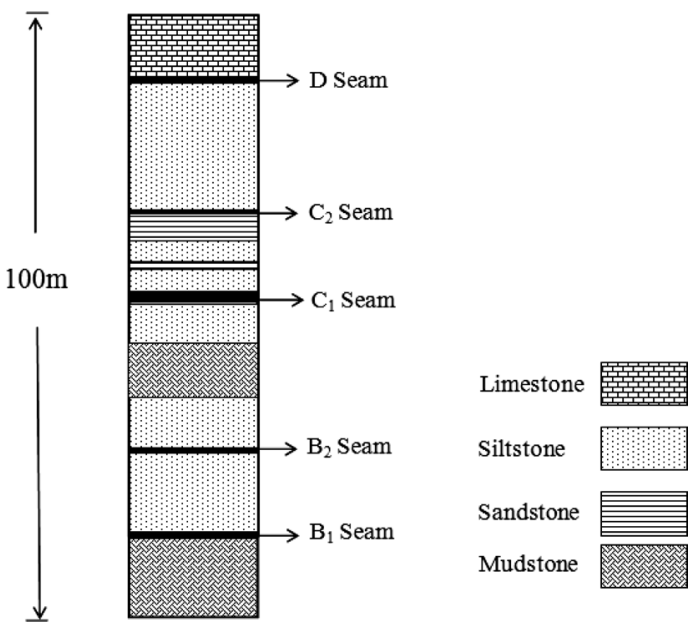

Figure 7: Generalized stratigraphic column at the Tabas coal mine (Anon, 2005)

major cleat set in respect to the $\mathrm{C}_{1}$ coal seam direction is almost vertical. The direction of one of the sub set of cleats in relation to the $\mathrm{C}_{1}$ seam direction is approximately parallel but with a plan plunge difference of 35 degrees relating to the horizon. The direction of the other is entirely parallel in relation to the $\mathrm{C}_{1}$ coal seam direction (Shahriar et al., 2009).

In this mine, a three-entry system was used for serving a $220 \mathrm{~m}$ long longwall face. There are two rows of chain pillars between two adjacent panels. Considering the dip of the coal seam, the first set of chain pillars is $200 \mathrm{~m}$ deep and the last one located along the lowest panel is approximately $700 \mathrm{~m}$ deep. The entries to the panels are $2.8 \mathrm{~m}$ high and $4.6 \mathrm{~m}$ wide. According to Fig- 
Table 3: The value of influencing parameters in the Tabas coal mine for methane drainage classification

\begin{tabular}{|l|l|l|}
\hline \multicolumn{2}{|l|}{ Parameters } & Value \\
\hline P1 & Coal Rank & Anthracite \\
\hline P2 & Moisture content (\%) & 0.36 \\
\hline P3 & Permeability of Coal (md) & 0.34 \\
\hline P4 & Cleat system (spacing (cm)) & 1.6 \\
\hline P5 & Ash content (\%) & 32 \\
\hline P6 & Gas content (m3/t) & 20 \\
\hline P7 & Degree of saturation (\%) & 51 \\
\hline P8 & Coal seam thicknesses (m) & 2.8 \\
\hline P9 & Coal seam depth (m) & 450 \\
\hline P10 & In-situ stress (MPa) & 11.5 \\
\hline P11 & $\begin{array}{l}\text { Geologic structure } \\
\text { of overburden }\end{array}$ & $\begin{array}{l}\text { High gas content } \\
\text { of surrounding rock }\end{array}$ \\
\hline P12 & Length of boreholes (m) & $50-150$ \\
\hline P13 & $\begin{array}{l}\text { Orientation of boreholes toward } \\
\text { the horizon (Degrees) }\end{array}$ & 20 \\
\hline P14 & Borehole stability & Moderately Stable \\
\hline P15 & Borehole spacing (m) & 20 \\
\hline P16 & Panel dimension (Width) (m) & 220 \\
\hline P17 & Cut depth (cm) & 80 \\
\hline
\end{tabular}

ure 7 , the $B_{1}$ and $B_{2}$ coal seams are located above and below the $\mathrm{C}_{1}$ coal seam and predicted after coal extraction the amount of gas entered to the mine working panel. Considering the high value of $\mathrm{C}_{1}$ gas content, a horizontal methane drainage wellbore was designed for this mine and its implementation was planned for a depth greater than $300 \mathrm{~m}$ (Anon, 2005).
This paper concerns the panel at a depth of $300 \mathrm{~m}$. The information of the Tabas coal mine for methane drainage classification is shown in Table 3.

\subsection{Determination CMD index for the Tabas coal mine}

For the determination of the coal seam methane drainageability index in the Tabas coal mine with the FRES method, the first step is the creation of an interaction matrix. For this purpose, by applying the arbitrations of specialists to the fuzzy system and using fuzzy rules on their views, the fuzzy interaction matrix was created and is shown in Table 4.

The second step consists of plotting a cause-effect diagram in order to identify dominant or subordinate parameters, and also interactive parameters. The parameter interaction intensity of each parameter is calculated according to Figure 8.

The C-E diagram of the affecting parameters on coal seam methane drainageability is plotted in Figure 9. The spots below the $\mathrm{C}=\mathrm{E}$ line are called dominant and the spots above the $\mathrm{C}=\mathrm{E}$ line are called subordinate. Conforming to this figure, along the $\mathrm{C}=\mathrm{E}$, the $\mathrm{C}+\mathrm{E}$ value increases.

It can be seen that gas content $\left(\mathrm{P}_{6}\right)$ is mostly a subordinate parameter (affected by the system). The more interactive parameter is the permeability of coal $\left(\mathrm{P}_{3}\right)$ and the less interactive parameter is ash content $\left(\mathrm{P}_{5}\right)$. The most dominate parameter is coal seam depth $\left(\mathrm{P}_{9}\right)$.

The interaction intensity histogram $(\mathrm{E}+\mathrm{C})$ for each parameter is shown in Figure 10. This histogram displays that small changes in the parameters $\mathrm{P}_{3}$ (Permeability of Coal), $\mathrm{P}_{6}$ (Gas Content) and $\mathrm{P}_{10}$ (In-situ stress)

Table 4: The fuzzy interaction matrix for coal seam methane drainageability

\begin{tabular}{|c|c|c|c|c|c|c|c|c|c|c|c|c|c|c|c|c|}
\hline P1 & 1.88973489 & 99999919 & 1.24654 & 1.50562 & 2.7534603 & 1.50562 & \begin{tabular}{|l|}
0.159211 \\
\end{tabular} & \begin{tabular}{|l|l|}
0.159738 \\
\end{tabular} & \begin{tabular}{|l|l|}
0.159211 \\
\end{tabular} & 0.159738 & 0.159738 & 0.159738 & \begin{tabular}{|l|}
0.182461 \\
\end{tabular} & 0.159738 & 15921 & 0.464948 \\
\hline 0.159738 & $\mathbf{P 2}$ & 1.26872294 & \begin{tabular}{|l|}
0.505321 \\
\end{tabular} & 0.159211 & 2.9999992 & \begin{tabular}{|l|}
3.238063 \\
\end{tabular} & \begin{tabular}{|l|}
0.157082 \\
\end{tabular} & \begin{tabular}{|l|}
0.159211 \\
\end{tabular} & \begin{tabular}{|l|}
0.159211 \\
\end{tabular} & 0.505321 & 0.159211 & 0.159211 & \begin{tabular}{|l|}
0.464948 \\
\end{tabular} & 0.159211 & \begin{tabular}{|l|}
0.159211 \\
\end{tabular} & 159211 \\
\hline 59738 & $\begin{array}{ll}3.05496666 \\
\end{array}$ & P3 & 1.20591 & \begin{tabular}{|l|l|}
0.464948 \\
\end{tabular} & 2.999999 & 2 & 0.159211 & 0.159738 & 0.159738 & 0.464948 & 0.464948 & 1.22246 & 1.22246 & 1.889735 & 0.464948 & 20591 \\
\hline 4948 & $\begin{array}{ll} & 1.05496666 \\
\end{array}$ & 3.84078917 & P4 & \begin{tabular}{|l|l|}
0.464948 \\
\end{tabular} & 2.6003345 & 889735 & 59211 & \begin{tabular}{|l|l|}
0.159211 \\
\end{tabular} & 1.054967 & 1.054967 & 1.054967 & 1.5 & & & 15973 & 2687 \\
\hline 1.746853 & \begin{tabular}{|l|l|}
3 & 0.15921061 \\
\end{tabular} & 0.76190955 & \begin{tabular}{|l|}
0.159211 \\
\end{tabular} & P5 & 0.7619096 & 1.20591 & \begin{tabular}{|l|l|}
0.157082 \\
\end{tabular} & \begin{tabular}{|l|l|l|l|}
0.15702 \\
\end{tabular} & \begin{tabular}{|l|l|}
0.157082 \\
\end{tabular} & 1.157082 & 157082 & 0.159211 & \begin{tabular}{|l|l|}
0.464948 \\
\end{tabular} & 0.159211 & \begin{tabular}{|l|l|}
0.159211 \\
\end{tabular} & 464948 \\
\hline 0.464948 & \begin{tabular}{|l|l|}
3.21346428 \\
\end{tabular} & 0.76190955 & 0.464948 & \begin{tabular}{|l|l|} 
& 0.159211 \\
\end{tabular} & $\mathrm{P6}$ & \begin{tabular}{|l|}
1.979523 \\
\end{tabular} & \begin{tabular}{|l|}
0.159211 \\
\end{tabular} & \begin{tabular}{|l|}
0.464948 \\
\end{tabular} & \begin{tabular}{|l|}
0.505321 \\
\end{tabular} & 0.159738 & 1.054967 & 1.054967 & \begin{tabular}{|l|}
0.159738 \\
\end{tabular} & 1.5 & \begin{tabular}{|l|}
0.182461 \\
\end{tabular} & 464948 \\
\hline 9211 & 19437974 & 1029 & 0.159211 & \begin{tabular}{|l|l|}
0.159211 \\
\end{tabular} & 3.8175391 & P7 & \begin{tabular}{|l|}
0.157082 \\
\end{tabular} & 59211 & \begin{tabular}{|l|}
0.159211 \\
\end{tabular} & 59211 & 1.054967 & 32461 & & 3723 & & \\
\hline 0.159211 & 5708173 & 0.46494846 & \begin{tabular}{|l|l|}
0.464948 \\
\end{tabular} & \begin{tabular}{|l|l|}
0.464948 \\
\end{tabular} & 9747828 & 000001 & P8 & 0.157082 & \begin{tabular}{|l|l|}
0.464948 \\
\end{tabular} & 464948 & 13464 & 0.464948 & 268723 & 889735 & 89735 & 2581 \\
\hline 2.080636 & \begin{tabular}{|l|l|}
50.18246091 \\
\end{tabular} & 99999 & 2.75346 & 0.505321 & 2.999999 & 1.50562 & \begin{tabular}{|l|}
0.157082 \\
\end{tabular} & P9 & 2.246538 & 1.268723 & 1.979523 & 1.889735 & & 1.50562 & 889735 & 1.399595 \\
\hline 1.24654 & 0.15921061 & 2.62609916 & 2.999999 & \begin{tabular}{|l|}
0.157082 \\
\end{tabular} & 1.2059103 & 1.24654 & 159211 & 1.054967 & P10 & 1.379981 & 1.213464 & 2.49438 & \begin{tabular}{|l|l|}
3.817539 \\
\end{tabular} & & $8 / 23$ & a \\
\hline 461 & 46494846 & 1.05496666 & 2.258227 & 0.182461 & 2.999999 & 2 & 9211 & 59738 & 2.999999 & 11 & 2 & 2 & 2.794035 & | & 6853 & 49438 \\
\hline 159211 & 0.15708173 & 1.74685313 & 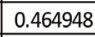 & \begin{tabular}{|l|l|} 
& 0.157082 \\
\end{tabular} & 0.1592106 & .464948 & 59211 & 59211 & 64948 & 159211 & P12 & 1.889735 & 1.24654 & 00335 & 13464 & 054967 \\
\hline 0.159211 & 0.15708173 & 1.68424763 & 0.159738 & \begin{tabular}{|l|l|}
0.157082 \\
\end{tabular} & 0.1592106 & 15973 & 59211 & 57082 & 64948 & 99211 & 9999 & P13 & 1.493939 & 9523 & 9948 & 18246 \\
\hline 9211 & 15708173 & & 0.159738 & \begin{tabular}{|l|l|} 
& 0.159211 \\
\end{tabular} & 59738 & 159211 & 9211 & 69211 & 9738 & 9211 & 58227 & 25816 & & 00001 & 2246 & 20591 \\
\hline 159211 & 0.15921061 & \begin{tabular}{|l|l|}
1.88973489 \\
\end{tabular} & 0.464948 & \begin{tabular}{|l|}
0.159211 \\
\end{tabular} & \begin{tabular}{|l|}
0.4649485 \\
\end{tabular} & 159738 & 59211 & 7082 & 4948 & 9211 & 1.974783 & 75346 & 1.000001 & 15 & 0.182461 & 0.464948 \\
\hline 0.159211 & 0.15708173 & \begin{tabular}{|c|}
0.76190955 \\
\end{tabular} & 0.464948 & \begin{tabular}{|l|l|}
0.157082 \\
\end{tabular} & 0.1592106 & \begin{tabular}{|l|}
0.505321 \\
\end{tabular} & \begin{tabular}{|l|}
0.159211 \\
\end{tabular} & \begin{tabular}{|l|}
0.159211 \\
\end{tabular} & \begin{tabular}{|l|}
0.464948 \\
\end{tabular} & 0.159738 & 0.464948 & 1.000001 & 1.20591 & 1.24654 & P16 & 2.25816 \\
\hline 0.159211 & 0.15708173 & \begin{tabular}{|l|}
0.46494846 \\
\end{tabular} & 0.76191 & 0.159211 & 0.159738 & 0.464948 & \begin{tabular}{|l|l|}
0.157082 \\
\end{tabular} & 0.157082 & 0.182461 & 0.159211 & 0.182461 & 0.505321 & 1.000001 & 1.000001 & 0.159738 & P17 \\
\hline \multicolumn{14}{|c|}{$\begin{array}{l}\text { P1: Coal Rank, P2: Moisture content, P3: Permeability of Coal, P4: Cleat system, P5: Ash content, P6: Gas } \\
\text { content, P7: Degree of saturation, P8:Coal Seam thicknesses, P9: Coal seam depth, P10: In-situ stress , P11: } \\
\text { Geologic structure of overburden, P12: Length of boreholes, P13: Orientation of boreholes to the principal } \\
\text { horizontal stress), P14: Boreholes stability, P15: Boreholes spacing, P16: Panel dimension, P17: Cut depth }\end{array}$} & $\begin{array}{l}\downarrow \\
\text { Inf } \\
\text { lue } \\
\text { nc } \\
\text { e } \\
\text { P1 } \\
7 \\
\text { on }\end{array}$ & & $\begin{array}{l}\text { Inf } \\
\text { lue } \\
\text { nc } \\
\mathrm{e} \\
\text { P1 } \\
5 \\
\text { on } \\
\text { P1 }\end{array}$ \\
\hline
\end{tabular}




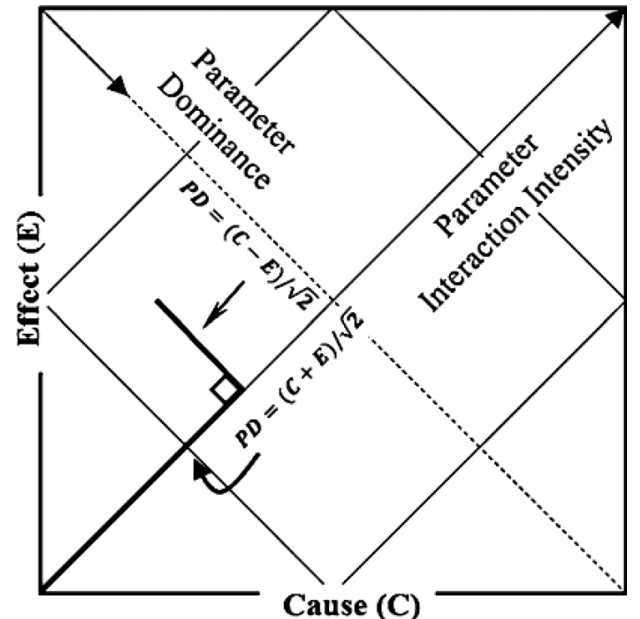

Figure 8: Equal parameter interaction intensity and dominance (Hudson, 1992)

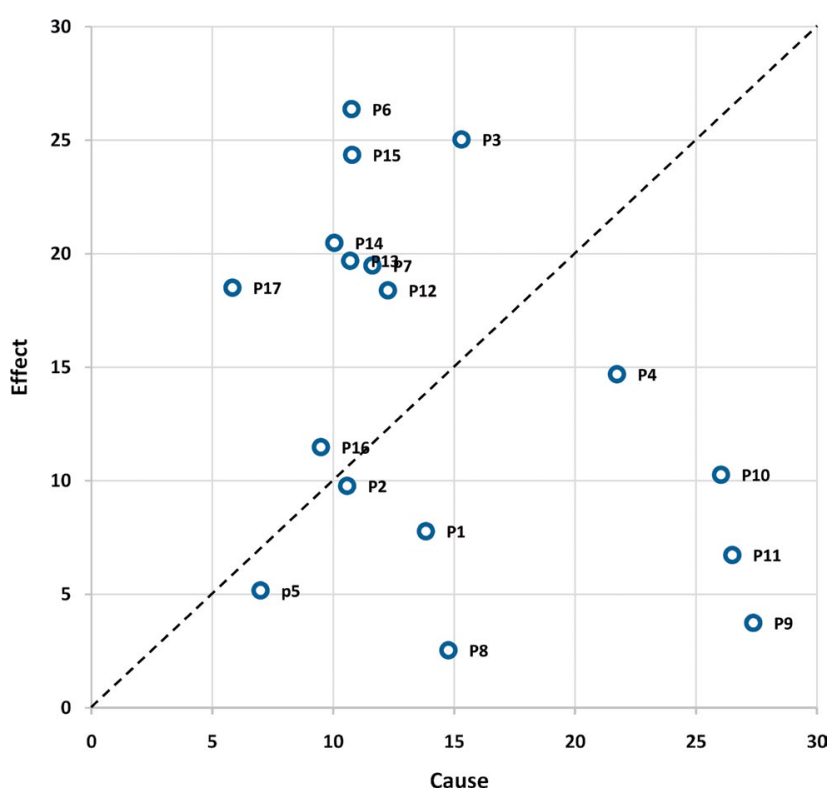

Figure 9: Cause-effect diagram
Table 5: The weighted coefficient

\begin{tabular}{|c|c|c|}
\hline Parameters & $C+E$ & $W_{i}(\%)$ \\
\hline P1 Coal rank & 21.60 & 0.884 \\
\hline P2 Moisture content & 20.35 & 0.832 \\
\hline P3 Permeability of coal & 40.34 & 1.650 \\
\hline P4 Cleat system (spacing) & 36.42 & 1.490 \\
\hline P5 Ash content & 12.16 & 0.497 \\
\hline P6 Gas content & 37.13 & 1.518 \\
\hline P7 Degree of saturation & 31.10 & 1.272 \\
\hline P8 Coal seam thicknesses & 17.29 & 0.707 \\
\hline P9 Coal seam depth & 31.10 & 1.272 \\
\hline P10 In-situ stress & 36.30 & 1.485 \\
\hline $\begin{array}{l}\text { P11 Geologic structure } \\
\text { of overburden }\end{array}$ & 33.23 & 1.359 \\
\hline P12 Length of boreholes & 30.65 & 1.254 \\
\hline $\begin{array}{l}\text { P13 Orientation of boreholes to } \\
\text { the principal horizontal stress }\end{array}$ & 30.39 & 1.243 \\
\hline P14 Boreholes stability & 30.52 & 1.248 \\
\hline P15 Boreholes spacing & 35.13 & 1.437 \\
\hline P16 Panel dimension (Width) & 20.97 & 0.857 \\
\hline P17 Cut depth & 24.34 & 0.995 \\
\hline
\end{tabular}

have a great effect in the system treatment. These parameters have a maximum value of $\mathrm{C}+\mathrm{E}$ in the system.

Base on the weight value (see Table 5) of each parameter, the coal seam methane drainageability index (CMDI) is calculated. The coal seam methane drainageability index is an expression of the inherent potential methane drainage of the coal seam, where the maximum value of the index is 100 and refers to very good conditions for pre-drainage techniques in a working mine. The classification of methane drainageability status for a coal seam is shown in Figure 11. CMDI ranges between 0 and 100; CMDI $<20$ indicates very bad conditions for

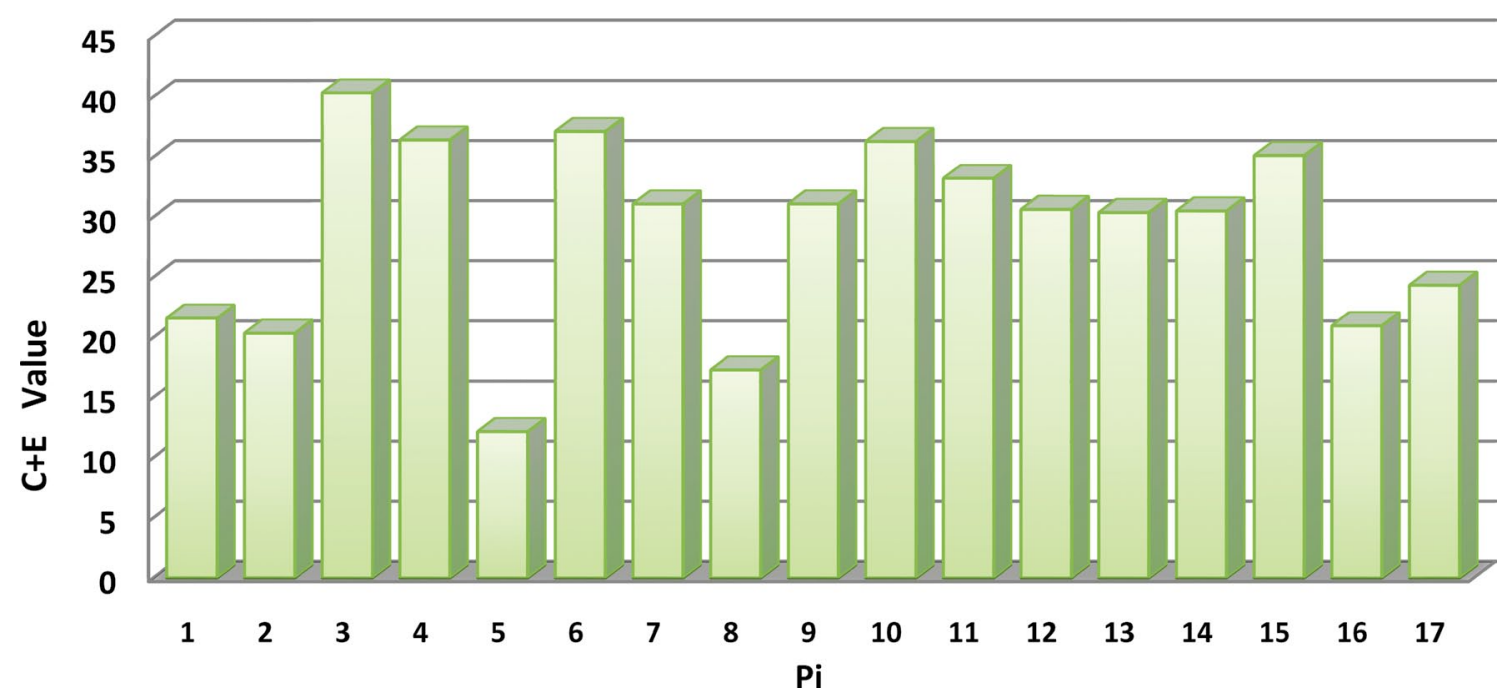

Figure 10: Histogram of interactive intensity of parameters 
methane drainage, $20<\mathrm{CMDI}<40$ corresponds to bad condition for methane drainage, $40<\mathrm{CMDI}<60$ corresponds to moderate conditions for methane drainage, 60

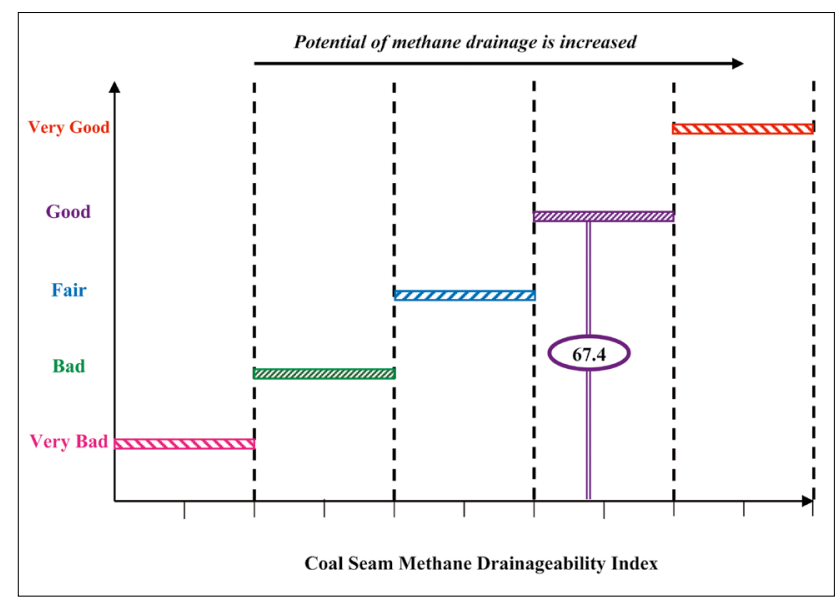

Figure 11: The classification of coalbed methane status
$<$ CMDI $<80$ corresponds to good conditions for methane drainage and $80<\mathrm{CMDI}<100$ corresponds to very good conditions for methane drainage. It should be noted that by increasing the CMDI, the potential of methane drainage from a working mine increases. Therefore, it is recommended that for CMDI values between 60 and 80, horizontal boreholes and gob gas ventholes be implemented and for CMDI values between 80 and 100, vertical boreholes and gob gas ventholes be implemented. In this study, the CMDI value for the Tabas coal mine is 67.4. This value indicates the methane drainage method could be implanted in this mine. In summary, the flow sheet for determining the coal seam methane drainageability by FRES is presented in Figure 12.

\section{Conclusion}

In this study, a new approach, namely, coal seam methane drainageability index (CMDI) is developed for

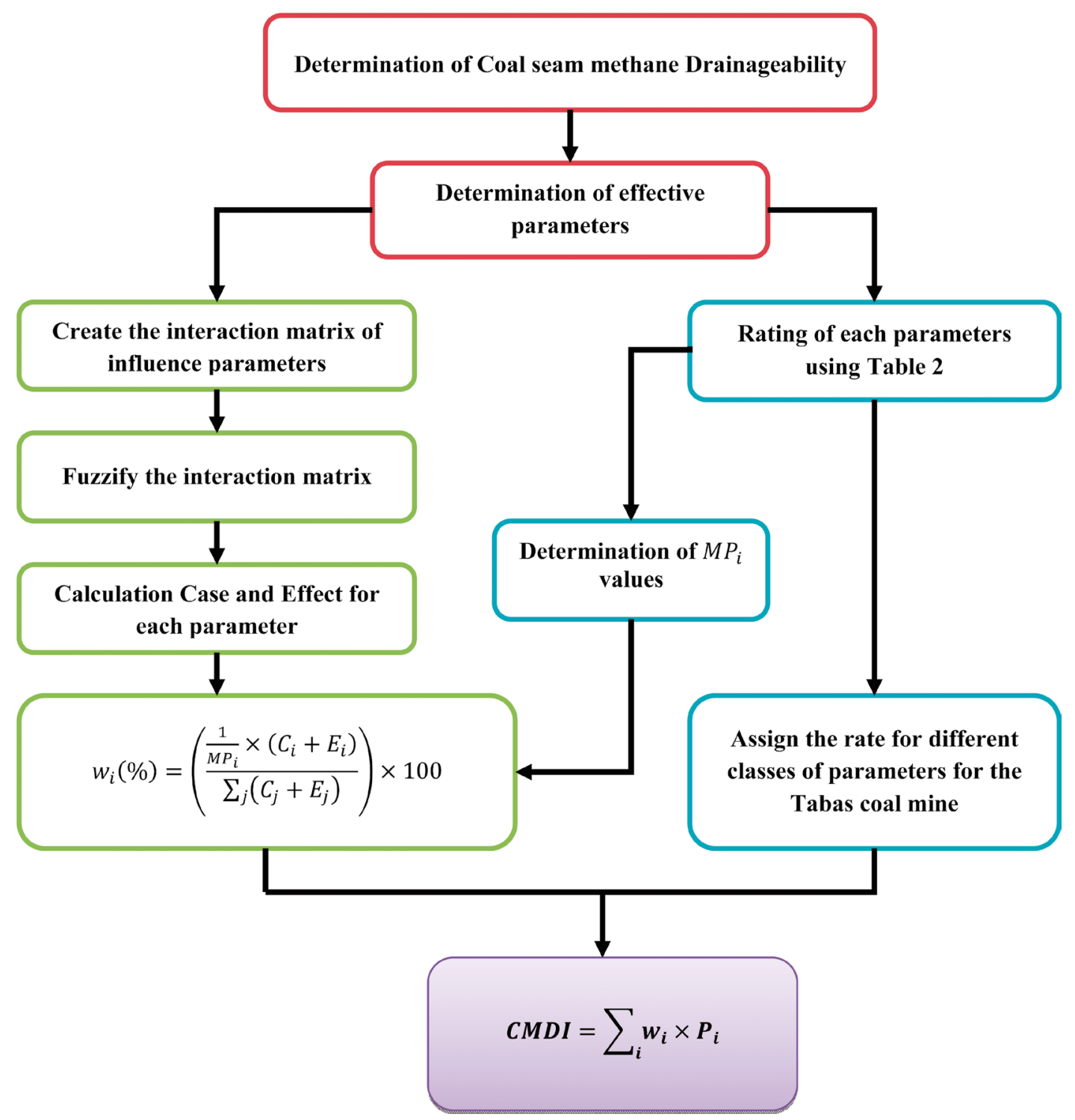

Figure 12: Flowchart in prediction CMDI using FRES 
the classification of coal seam methane draingeability. In this study, after initial studies, the most important parameters (17 parameters) affecting methane drainage were selected. In the CMDI approach, the classification of a coal seam is based on the fuzzy rock engineering system. Accordingly, the first step is creating an interaction matrix by applying the fuzzy system to judgments of experts and using fuzzy rules on their views. Then a cause-effect diagram is plotted using the values of cause and effect parameters. By calculating the coefficient values of each parameter and performing a summation of the multiplication of them to assigned values for each input parameter, the coal seam methane draingeability index is calculated. According to this new approach, the following conclusions have been made:

- The effect of each parameter on methane drainage from the coal seam in a working mine is evaluated. The results obtained from a cause-effect diagram show that the permeability of coal $\left(\mathrm{P}_{3}\right)$ is the most interactive parameter. In other words, a small change in this parameter causes a large change in the system. The most dominant parameter is coal seam depth $\left(\mathrm{P}_{9}\right)$ and the most subordinate parameter is gas content $\left(\mathrm{P}_{6}\right)$.

- The application of this new approach at the Tabas coal mine for the classification $\mathrm{C}_{1}$ coal seam showed that the $\mathrm{C}_{1}$ coal seam is located in a good zone for methane drainage.

The presented index based on the fuzzy RES is a suitable method which provides a reliable result for the prediction coal seam methane drainageability. However, such a proposed index usually requires future research for incorporating other parameters which may be critical for methane drainage from a coal seam. It should be noted that the present index is suitable for pre-drainage in a working mine, and is not necessarily appropriate for post-drainage techniques.

\section{References}

Aminian, K., Ameri, S., Bhavsar, A., Sanchez, M., Garcia, A. (2004): Type curves for coalbed methane production prediction. Society of Petroleum Engineers, doi.org/10.2118/ 91482-MS.

Andrieux, P., Hadjigeorgiou, J. (2008): The destressability index methodology for the assessment of the likelihood of success of a large-scale confined destress blast in an underground mine pillar. International journal of rock mechanics and mining sciences, 45, 407-421.

Anon, (2005): Basic Design of Tabas Coal Mine Project, Report-Mining. Volume 1, $210 \mathrm{p}$.

Balan, H. O., Gumrah, F., (2009): Assessment of shrinkageswelling influences in coal seams using rank-dependent physical coal properties. International Journal of Coal Geology, 77, 203-213.

Black, D. J., (2011): Factors affecting the drainage of gas from coal and methods to improve drainage effectiveness. $\mathrm{PhD}$ thesis, University of Wollongong.
Black, D. Aziz, N. (2011): Actions to improve coal seam gas drainage performance. In N. Aziz, B. kininmonth, J. Nemcik T. Ren (Eds.), $11^{\text {th }}$ Underground Coal Operators' Conference (307-314). Wollongong Australia: University of Wollongong Printery.

Comfort, V. P. C. S. W., Reserves, I. C. (1999): Guidebook on Coalbed Methane Drainage for Underground Coal Mines.

Dai, L. C., Wen, G. C., Liu, Z., Yang, H. M., Wang, B. (2013): Analysis of Geological Factors Affecting Coal Seam Gas Content and Prediction. In Advanced Materials Research (Vol. 634, 3645-3649). Trans Tech Publications.

Darling, P. (2011): SME mining engineering handbook. Denver: Society for Mining, Metallurgy, and Exploration.

Diamond, W. P. (1994): Methane control for underground coal mines. US Department of the Interior, Bureau of Mines.

Dougherty, H. N., Karacan, C. Ö. (2011): A new methane control and prediction software suite for longwall mines. Computers \& geosciences, 37, 149.

Flores, R. M. (1998): Coalbed methane: from hazard to resource. International Journal of Coal Geology, 35, 3-26.

Gale, J., \& Freund, P. (2001): Coalbed Methane Enhancement with $\mathrm{CO} 2$ Sequestration Worldwide Potential. Environmental Geosciences, 8, 210-217.

Hamawand, I., Yusaf, T., Hamawand, S. G. (2013): Coal seam gas and associated water: a review paper. Renewable and Sustainable Energy Reviews, 22, 550-560.

Hemza, P., Sivek, M., Jirásek, J. (2009): Factors influencing the methane content of coal beds of the Czech part of the Upper Silesian Coal Basin, Czech Republic. International Journal of Coal Geology, 79, 29-39.

Huang, H., Shuxun, S. A. N. G., Liangcai, F. A. N. G., Guojun, L. I., Hongjie, X. U., Bo, R. E. N. (2010): Optimum location of surface wells for remote pressure relief coalbed methane drainage in mining areas. Mining Science and Technology (China), 20, 230-237.

Huang, R., Huang, J., Ju, N., \& Li, Y. (2013): Automated tunnel rock classification using rock engineering systems. Engineering Geology, 156, 20-27.

Hudson, J. (1992): Rock engineering systems. Theory and Practice.Horwood, Chicester,p.185. doi.org/10.1016/01489062(95)00038-I

Karacan, C. Ö. (2009a): Degasification system selection for US longwall mines using an expert classification system. Computers \& Geosciences, 35, 515-526.

Karacan, C. Ö. (2009b): Forecasting gob gas venthole production performances using intelligent computing methods for optimum methane control in longwall coal mines. International Journal of Coal Geology, 79, 131-144.

Karacan, C. Ö. (2010): Methane control and prediction (MCP) software (version 2.0). Pittsburgh, PA: U.S. Department of Health and Human Services, Public Health Service, Centers for Disease Control and Prevention, National Institute for Occupational Safety and Health, $100 \mathrm{p}$.

Karacan, C. Ö., Diamond, W. P., Esterhuizen, G. S., Schatzel, S. J. (2005): Numerical analysis of the impact of longwall panel width on methane emissions and performance of gob gas ventholes. In Proceedings of International Coalbed Methane Symposium, Paper (Vol. 505). 
Karacan, C. Ö., Ruiz, F. A., Cotè, M., Phipps, S. (2011): Coal mine methane: a review of capture and utilization practices with benefits to mining safety and to greenhouse gas reduction. International Journal of Coal Geology, 86, 121-156.

Karacan, C. Ö., Ulery, J. P., Goodman, G. V. R. (2008): A numerical evaluation on the effects of impermeable faults on degasification efficiency and methane emissions during underground coal mining. International Journal of Coal Geology, 75, 195-203.

Laubach, S. E., Marrett, R. A., Olson, J. E., Scott, A. R. (1998): Characteristics and origins of coal cleat: a review. International Journal of Coal Geology, 35, 175-207.

Laxminarayana, C., Crosdale, P. J. (1999): Role of coal type and rank on methane sorption characteristics of Bowen Basin, Australia coals. International Journal of Coal Geology, 40, 309-325.

Levy, J. H., Day, S. J., Killingley, J. S. (1997): Methane capacities of Bowen Basin coals related to coal properties. Fuel, 76, 813-819.

Liu, B., Ao, W. H., Huang, W. H., Xu, Q. L., Teng, J. (2014) : Comprehensive Analysis of Factors Affecting Coalbed Methane Productivity: A Case Study of Southern Qinshui Basin. In Advanced Materials Research, 962, 21-28, Trans Tech Publications.

Liu, J., Spiers, C. J., Peach, C. J., Vidal-Gilbert, S. (2016): Effect of lithostatic stress on methane sorption by coal: Theory vs. experiment and implications for predicting in-situ coalbed methane content. International Journal of Coal Geology, 167, 48-64.

Moore, T. A. (2012): Coalbed methane: a review. International Journal of Coal Geology, 101, 36-81.

Naghadehi, M. Z., Jimenez, R., KhaloKakaie, R., Jalali, S. M. E. (2013): A new open-pit mine slope instability index defined using the improved rock engineering systems approach. International Journal of Rock Mechanics and Mining Sciences, 61, 1-14.

Naghadehi, M. Z., Jimenez, R., KhaloKakaie, R..,Jalali, S. M. E. (2013): A new open-pit mine slope instability index defined using the improved rock engineering systems approach. International Journal of Rock Mechanics and Mining Sciences, 61, 1-14.

Najafi, M., Jalali, S. M. E., KhaloKakaie, R. (2014): Thermalmechanical- numerical analysis of stress distribution in the vicinity of underground coal gasification (UCG) panels. International Journal of Coal Geology, 134, 1-16.

Paul, S., Chatterjee, R. (2011): Determination of in-situ stress direction from cleat orientation mapping for coal bed methane exploration in south-eastern part of Jharia coalfield, India. International Journal of Coal Geology, 87, 87-96.

Rafiee, R., Ataei, M., KhalooKakaie, R. (2015 a): A new cavability index in block caving mines using fuzzy rock engineering system. International Journal of Rock Mechanics and Mining Sciences, 77, 68-76.

Rafiee, R., Ataei, M., Khalokakaie, R., Jalali, S. M. E., Sereshki, F. (2015 b): Determination and assessment of parameters influencing rock mass cavability in block caving mines using the probabilistic rock engineering system. Rock Mechanics and Rock Engineering, 48, 1207-1220.

Rafiee, R., Khalookakaie, R., Ataei, M., Jalali, S. M. E., Sereshki, F., \& Azarfar, A. (2016): Improvement of rock engineering system coding using fuzzy numbers. Journal of Intelligent \& Fuzzy Systems, 30, 705-715.

Rozos, D., Pyrgiotis, L., Skias, S., Tsagaratos, P. (2008): An implementation of rock engineering system for ranking the instability potential of natural slopes in Greek territory. An application in Karditsa County. Landslides, 5, 261-270.

Saeidi, O., Torabi, S. R., Ataei, M. (2013): Development of a New Index to Assess the Rock Mass Drillability. Geotechnical and Geological Engineering, 31, 1477-1495.

Saghafi, A. (2016): Determination of the Gas Content of Coal. Coal Operators' Conference.

Sereshki, F. (2005): Improving coal mine safety by identifying factors that influence the sudden release of gases in outburst prone zones (Doctoral dissertation, University of Wollongong).

Shahriar, K., Bakhtavar, E., Moeinizadeh, A. (2009): Some experiments in-situ and in laboratory to determine the physico-mechanical properties of coal. Gospodarka Surowcami Mineralnymi, 25, 79-96.

Shang, Y. J., Wang, S. J., Li, G. C., Yang, Z. F. (2000): Retrospective case example using a comprehensive suitability index (CSI) for siting the Shisan-Ling power station, China. International Journal of Rock Mechanics and Mining Sciences, 37, 839-853.

Sivek, M., Jirásek, J., Sedláčková, L., Čáslavský, M. (2010); Variation of moisture content of the bituminous coals with depth: A case study from the Czech part of the Upper Silesian Coal Basin. International Journal of Coal Geology, 84, 16-24.

Thakur, P. (2014): Coal seam degasification. Coal Bed Methane: From Prospect to Pipeline, $155 \mathrm{p}$.

Ting, F. T. C. (1977): Origin and spacing of cleats in coal beds. Journal of Pressure Vessel Technology, 99, 624-626.

Warmuzinski, K. (2008): Harnessing methane emissions from coal mining. Process Safety and Environmental Protection, 86, 315-320.

Wilson, D. R., Lively, P., Sandarusi, J. A., Bowser, P., Stanley, M. (1995): U.S. Patent No. 5,402,847. Washington, DC: U.S. Patent and Trademark Office.

Wong, S., Law, D., Deng, X., Robinson, J., Kadatz, B., Gunter, W. D., Zhiqiang, F. (2007): Enhanced coalbed methane and $\mathrm{CO} 2$ storage in anthracitic coals-Micro-pilot test at South Qinshui, Shanxi, China. International Journal of Greenhouse Gas Control, 1, 215-222.

Ying, C. (2010): The Study of Control Action of Fault on Coal and Gas Outburst. International Mining Forum.

Younessi, A., Rasouli, V. (2010): A fracture sliding potential index for wellbore stability analysis. International Journal of Rock Mechanics and Mining Sciences, 47, 927-939.

Zawadzki, J., Fabijańczyk, P., Badura, H. (2013): Estimation of methane content in coal mines using supplementary physical measurements and multivariable geostatistics. International Journal of Coal Geology, 118, 33-44.

Zhang, L. Q., Yang, Z. F., Liao, Q. L., Chen, J. (2004): An application of the rock engineering systems (RES) methodology in rockfall hazard assessment on the Chengdu-Lhasa highway, China. International Journal of Rock Mechanics and Mining Sciences, 41, 833-838. 


\section{SAŽETAK}

\section{Razvoj novoga indeksa propusnosti metana u slojevima ugljena uporabom inženjerskoga sustava temeljenoga na neizravnoj logici}

Ugljeni plin jedan je od najvažnijih izvora energije iz nekonvencionalnih plinskih ležišta. Prepoznavanje varijabli koji utječu na propusnost metana važno je za sve buduće projekte iskorištavanja takvih ležišta. Kod crpenja takvih metanskih ležišta efikasnost je određena prirodnim i operacijskim čimbenicima. Prikazan je novi metanski indeks crpenja (MIC, engl. skr. CMDI) kao vrijednost za uporabu u rudarskim zahvatima. Razmatrano je 17 glavnih parametara koji utječu na crpenje metana iz ugljena, svrstanih u matricu kreiranu na temeljima neizravne logike stijenskoga sustava. Zatim je analiziran odnos parametara koji utječu na crpenje. Budući da odnosi u neizravnim logičkim modelima nisu jedinstveni, takav sustav pažljivo je prilagođen kako bi minimizirao subjektivnost u određivanju težinskih faktora pojedinačnih parametara. Primjer uporabe modela prikazan je za rudnik ugljena Tabas u Iranu. Na uzorcima iz sloja C1 toga prostora primijenjen je izračun indeksa crpenja. Rezultati su pokazali kako takav indeks može vrlo uspješno predvidjeti moguću proizvodnju metana te biti uporabljen kao varijabla za donošenje odluka i smanjenje rizika negativnih događaja u takvim projektima.

\section{Ključne riječi:}

crpenje metana, stijenski inženjerski sustav, sustavi neizravne logike, nekonvencionalni plin, rudnik ugljena Tabas

\section{Authors contribution}

Mehdi Najafi is an associate professor at the Department of Mining and Metallurgical Engineering, Yazd University, Iran from 2014 to present. Najafi's research interests include underground mine planning, numerical modeling, ground control, coal mining and pillar design. Ramin Rafiee is an assistant professor at the Faculty of Mining Eng., Petroleum and Geophysics, Shahrood University of Technology, Iran from 2105 to present. Rafiee's research interests include fuzzy systems and underground mines. 